\title{
Harapan Orang tua Memberi Nama Anak di Daerah Mandailing
}

\author{
Novita Trianto Hasibuan \\ Universitas Negeri Medan
}

\begin{abstract}
Abstrak
Nama merupakan identitas yang sangat penting karena nama merupakan atribut yang sangat pribadi, yang memiliki fungsi sebagai identifikasi seseorang. Oleh karena itu, bagi orang tua pemberian nama sangatlah penting, karena nama merupakan doa orang tua yang diberikan untuk seorang anak. Nama merupakan bahasa komunikasi manusia, maka penamaan anak oleh orang tua akan berbeda-beda antara orang tua yang satu dengan yang lainnya. Nama anak merupakan bahasa yang mewakili bahasa pikiran orang tua yang terasosiasi dengan lingkungannya. Setiap orang tua memiliki alasan dan harapan tersendiri pada nama yang diberikan kepada anaknya. Masyarakat Batak memiliki nama-nama khas. Nama menurut orang tua, bisa membawa hal baik, keberuntungan dan juga diketahui dari mana seseorang itu berasal. Hasil penelitian ini diharapkan penulis bisa mengetahui dan menarik kesimpulan dari kajian sosiolinguistik terhadap hubungan nama anak dengan harapan orang tua. Penelitian ini bermanfaat bagi kalangan yang ingin mengkaji ulang tentang nama-nama orang khususnya di daerah mandailing. Berdasarkan hasil penelitian tersebut terlihat bahwa nama-nama orang mandailing terjadi hubungan erat antara nama anak dengan harapan orang tuanya sebagai seorang batak. Dilihat dari arti nama masing-masing anak menunjukan makna nama yang mengagungkan, kebaikan, kegagahan, kelembutan, pesona yang menawan, penghambaan, dan ketaatan. Para orang tua berusaha memberikan nama-nama anaknya dengan nama yang terbaik menurut mereka.
\end{abstract}

Kata Kunci : nama anak, harapan orang tua.

\section{Abstract}

Name is very important identity, because name is an attribute that very personal, which has a function as an identification of a person. Because of that giving name to their child for parents is so important, because name is pray from parents to their child. The name is the language of human communication, there for the naming of a child by a parent will vary from one parent to another. The child's name is a language that represents the language of the mind of parents associated with the environment. Each parent has their own reasons and expectations of the names given to their children. Batak communities have distinctive names. Name according to the parents, can bring good luck and is also known where someone is coming.The results of this study are expected to know and the authors draw conclusions from the study of the relationship name sociolinguistic children with parental expectations. This research is helpful for those who want to review the names of people, especially in the area Mandailing.Based on these results it appears that the names of the Mandailing occur close relationship between the child's name and the hope of his parents as a vagabond. viewing from the meaning of the name of each student indicates that exalts the name meaning, goodness, valor, tenderness, charm, servitude and obedience. The parents tried to give the names of their children with the best name in their opinion.

Key Words : Child's name, parental expectations 


\section{PENDAHULUAN}

Fungsi pertama bahasa adalah penamaan. Nama diri sendiri adalah simbol pertama dan utama bagi seseorang. Nama juga dapat melambangkan status, cita rasa budaya, untuk memperoleh citra tertentu (pengelolaan kesan) atau sebagai nama hoki. Nama pribadi adalah unsur penting identitas seseorang dalam masyarakat, karena interaksi dimulai dengan nama kemudian diikuti dengan atributatribut lainnya.

Menurut Zunairoh (2014) Banyak sekali hal yang melatarbelakangi pemberian nama kepada seseorang dan terdapat berbagai macam keunikan-keunikan yang ada dalam pemberian nama. Keunikan-keunikan itu terdapat pada nama mereka misalnya nama Kliwon, Sapar, Wage, Siti, Nur merupakan nama - nama orang terdahulu. Sedangkan di zaman modern ini nama -nama tersebut sudah jarang ditemui. Dewasa ini, banyak sekali penamaan orang dengan tidak mempertimbangkan makna dan hanya terpengaruh oleh media disebabkan karena semakin pesatnya teknologi. Teknologi zaman sekarang sangat canggih, sehingga banyak sekali orang yang memberikan nama yang diambil dari sesuatu yang terkenal, seperti peristiwa penting bahkan orang yang terkenal dimasa itu.

Nama jelas bersifat simbolik, nama yang dianggap bagus menimbulkan kesan yang positif pada pendengar atau pembaca nama itu. Shakespeare, lewat tokoh Juliette-nya mengatakan apalah arti sebuah nama, Bunga ros akan tetap harum juga meski diberi nama lain. Akan tetapi, menurut penelitian psikologi, pendapat Juliette itu keliru. Nama anda memengaruhi cara mereka mempersepsi anda, pengharapan mereka akan anda, dan cara mereka memperlakukan anda.

Karena nama merupakan bahasa komunikasi manusia, maka penamaan anak oleh orang tua akan berbeda-beda antara orang tua yang satu dengan yang lainnya. Nama anak merupakan bahasa yang mewakili bahasa pikiran orang tua yang terasosiasi dengan 
lingkungannya. Setiap orang tua memiliki alasan dan harapan tersendiri pada nama yang diberikan kepada anaknya. Ada banyak faktor yang melandasi penamaan anak oleh orang tua, seperti nama gabungan, idealisme, tokoh masyarakat, tokoh pewayangan, harapan, dan bahkan nama anak yang dipakai terkadang diberikan orang tua karena terdapat suatu kaitan dengan peristiwa tertentu.

Terdapat bukti bahwa namanama yang lazim memberikan kesan lebih baik daripada nama-nama kurang lazim. Suatu penelitian menemukan bahwa penyandang nama seperti David, James, John, Joseph, Michael, dan Paul dipandang lebih kuat dan lebih aktif dari pada penyandang nama seperti Bernard, Edmond, dan Raymond. Bahkan anak-anak pun punya stereotip mengenai nama, dan streotip ini memengaruhi interaksi mereka dengan teman sebaya. Nama-nama yang agak lazim cenderung lebih populer daripada nama yang kurang lazim.

Sekarang kita mengerti mengapa banyak sekali seniman-seniman atau pekerja layar televisi mengubah namanya hanya untuk kepopuleran atau sebagai nama hoki. Misal Yuni Shara yang nama aslinya Wahyu Setyaning Budi, Ayu Azhari dengan nama aslinya Siti khadijah, Iwan Fals dengan nama aslinya Virgiawan Lisgianto, dan masih banyak lagi.

Alasan perubahan nama
seperti di atas sepertinya bukan
semata-mata masalah hoki,
melainkan masalah persepsi
masyarakat yang mungkin berkaitan
dengan masalah hoki juga. Nama
hewan pun dapat berfungsi sebagai
simbol. Anjing misalnya, punya
konotasi yang paling buruk di antara
nama-nama binatang, setidaknya di
Indonesia. buktinya, semburan kata
Anjing kepada seseorang begitu
menyakitkan dan bisa membuat
orang marah. Efeknya akan berbeda
jika dalam bentakan itu kata anjing
diganti dengan binatang lain seperti,
ayam, kelinci, angsa atau lainnya
yang mempunyai konotasi yang jauh
lebih baik daripada Anjing.

Alasan perubahan nama

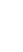


Penelitian tentang nama- dan juga merupakan suatu harapan, nama orang pernah dilakukan oleh restu atau doa.

Suranto (1983) yang berjudul Studi Tentang Nama-nama Jawa, Kajian ini merupakan kajian rintis yang menyediakan berbagai informasi dan data awal. Perihal yang menarik dari kajian ini adalah penegasan Suranto bahwa nama diri tidak hanya dapat dikaji dari aspek struktur kebahasaannya saja, tetapi juga memungkinkan untuk ditelaah dari aspek-aspeknya yang lain (sociocultural). Selain itu, penelitian Suharno (1987) yang berjudul Nama Diri dalam Masyarakat Merupakan Kajian yang Lebih Lengkap. Suharno mencoba merangkum berbagai upacara tradisional yang dilakukan oleh orang-orang dalam proses pemberian nama, menyambut kelahiran, dan juga bentuk social spirit dari masyarakat.

Masyarakat Batak memiliki nama-nama khas. Nama menurut orang tua, bisa membawa hal baik, keberuntungan dan juga diketahui dari mana seseorang itu berasal. Di kalangan suku Batak sebagaimana suku lainnya, nama memiliki makna

\section{LANDASAN TEORI}

\section{Fungsi dan Kedudukan Nama}

Menurut Wibowo (2001:51—52) fungsi penamaan nama diri dalam masyarakat terdiri lima belas fungsi.

1. Sebagai penanda identitas. Fungsi ini dipakai untuk memberi nama pada diri seseorang sekadar untuk membedakan dengan yang lain.

2. Sebagai penanda yang berkaitan dengan harapan, cita- cita, atau makna /tujuan baik.

3. Sebagai penanda penghormatan yang diwujudkan dengan pelekatan bentuk honorifik, ditandai dengan kata kyai, ki, nyai, nyi, ndara, den, dan s ebagainya) di depan nama diri.

4. Sebagai penanda kewibawaan yang ditunjukkan dengan 
pemilihan kata yang bernilai rasa hormat atau tinggi.

5. Sebagai penanda profesi yang ditunjukkan dengan pelekatan profesi yang digeluti sebagai komponen kedua dari nama diri.

6. Sebagai penanda urutan yang ditunjukkan dengan pelekatan pemarkah urutan sebagai komponen penamaan.

7. Sebagai penanda historisitas yang ditunjukkan dengan acuan peristiwa atau keadaan kelahiran orang itu.

8. Sebagai penanda jenis kelamin yang ditunjukkan dengan pelekatan nama atau komponen yang berasosiasi dengan jenis kelamin.

9. Sebagai penanda religiusitas atau ideologis.

10. Sebagai penanda kekerabatan yang ditunjukkan dengan pelekatan nama keluarga sebagai komponen kedua/ketiga nama diri.
11. Sebagai penanda keakraban yang ditunjukkan dengan pemendekan nama.

12. Sebagai penanda yang berkaitan dengan humor, paraban/julukan atau olok olok yang ditunjukkan dengan pelekatan salah satu kondisi bagian tubuh (pars pro toto atau part whole relation) atau asosiasi dengan sesuatu acuan lain.

13. Berkaitan dengan fungsi kerahasian yang ditunjukk an dengan penamaan lain (alias).

14. Berkaitan dengan pemertahanan gengsi atau keperluan bergaya.

15. Berfungsi teknonimi, yakni pelekatan nama anak sulung dibelakang nama orang tua, atau generasi pendahulunya sebagai pengganti nama diri sehingga muncul dalam tuturan lisan.

Menurut Hofmann, (1993:117) Nama adalah sesuatu yang dapat dipahami dan disebut oleh seseorang berupa kata, istilah, atau ungkapan 
yang dapat digunakan untuk mengenali seseorang atau sesuatu dari yang lainnya

Dalam KBBI (2008:950) nama adalah kata untuk menyebut atau memanggil orang (tempat, barang, binatang, dan sebaga inya) ataupun sebuah gelar atau sebutan, kemashuran, kebaikan (keunggulan) dan kehormatan.

Menurut Djajasudarma (1999 :30) Dunia ini penuh dengan nama- nama yang diberikan oleh manusia. Manusia tidak hanya memberi nama, tetapi memberi makna. Bahkan manusia diberi nama dan bermakna. Nama merupakan katakata yang menjadi label setiap makhluk, benda, aktivitas, dan peristiwa di dunia. Nama muncul akibat dari kehidupan manusia yang kompleks dan beragam

\section{Kedudukan nama dalam} kehidupan manusia berfungsi sebagai identitas dan penjaga hubungan sosial sehingga kelangsungan komunikasi antar manusia yang satu dengan yang lainnya menjadi lancar. Fungsi bahasa merupakan interaksional, yaitu fungsi yang mengacu pada pembinaan mempertahankan hubungan sosial antar penutur dengan menjaga kelangsungan komunikasi.

Dalam memberikan nama anak, setiap orang tua memiliki tujuan dan harapan tersendiri sebagai implementasi pikirannya. Nama seorang anak seperti halnya bahasa bisa memberikan gambaran jalan pikiran dari orang tuanya. Hipotesis Sapir-Whorf yang bila disederhanarkan akan berarti bahwa jalan pikiran manusia dibentuk oleh bahasa yang dipakainya atau bahasa menentukan cara dan jalan pikir manusia. Suatu bangsa yang berbeda bahasanya dari suatu bangsa akan mempunyai jalan pikiran yang berbeda pula. Perbedaan-perbedaan budaya dan jalan pikiran manusia berhulu dari perbedaan. Tanpa adanya bahasa, manusia tidak mempunyai pikiran sama sekali

Para ahli sosiologi berpendapat bahwa nama yang diberikan orang tua kepada anaknya akan memengaruhi kepribadian, kemampuan anak dalam berinteraksi 
dengan orang lain, dan bagaimana cara orang menilai diri pemilik namanya. Nama orang di dalam lingkungan masyarakat tidak saja berhubungan dengan agen penyandang atau keluarganya saja, tetapi berkait rapat dengan aspek yang lain, misalnya waktu, tempat, suasana atau peristiwa, status sosial, sejarah, dan tradisi. Nama merupakan produk masyarakat yang mampu menjelaskan berbagai hal tentang masyarakat itu Inilah yang menarik, mengapa nama dapat merujuk ide-ide yang abstrak, seperti budaya, masyarakat, nilai, cita-cita, harapan, dan doa (Cavallaro, 2004).

\section{Alasan Orang tua Memberikan Nama Kepada Anaknya}

Banyak alasan dan pertimbangan para orang tua dalam memilihkan nama anak. Ada yang menyukai anaknya memiliki nama yang unik dan tidak 'pasaran'. Hal ini dikarenakan orang tua khawatir ketika nama anaknya dipanggil di depan umum, ternyata ada banyak anak yang menoleh karena kebetulan namanya sama. Ada yang lebih suka anaknya memiliki nama yang singkat dan mudah diingat. Orang tua seperti ini memiliki alasan, bahwa anaknya kelak ketika dipanggil akan memakai nama bapaknya di belakang namanya. Walaupun pernah kejadian orang Indonesia yang diharuskan mengisi suatu formulir di negara Eropa sedikit kebingungan karena diharuskan mengisi kolom nama keluarga. Padahal sebagaimana juga kebanyakan orang Indonesia, nama yang ada di kartu indentitasnya hanya nama tunggal, tanpa nama keluarga atau bin/binti.

Beberapa orang tua lain memilihkan nama yang megah untuk anak mereka. Sementara bagi kalangan tertentu ada kepercayaan jika anak 'keberatan nama' nanti bisa sakit-sakitan. Sebagian orang ada yang menganggap nama sebagai sesuatu yang biasa, sekedar identitas yang membedakan seseorang dengan yang lain. Ada lagi yang memilihkan nama untuk anaknya berdasarkan rasa penghargaan terhadap seseorang yang dianggap telah berjasa atau dikagumi. Sebagai orang tua, kita perlu tahu makna dari sebuah nama 
dan mempertimbangkan yang terbaik untuk anak kita. Bayangkan bahwa anak kita akan menyandang nama tersebut sejak tertulis di akte kelahiran, hingga di hari akhir nanti.

Orang tua seharusnya berusaha memberikan sebutan nama yang baik, indah dan disenangi anak, karena nama seperti itu dapat membuat mereka memiliki kepribadian yang baik, memumbuhkan rasa cinta dan menghormati diri sendiri. Kemudian mereka kelak akan terbiasa dengan akhlak yang mulia saat berinteraksi dengan orang-orang di sekelilingnya. Anak juga perlu mengetahui dan paham tentang arti namanya. Pemahaman yang baik terhadap nama mereka akan menimbulkan perasaan memiliki, perasaan nyaman, bangga dan perasaan bahwa dirinya berharga.

Bagi lingkungan keluarga, adalah hal yang penting untuk menjaga agar nama anak-anak mereka disebut dan diucapkan dengan baik pula. Sebab ada kebiasaan dalam masyarakat kita yang suka mengubah nama anak dengan panggilan, julukan, atau nama kecil. Sayangnya nama panggilan ini terkadang malah mengacaukan nama aslinya. Nama panggilan ini kadang selain tidak bermakna kebaikan juga bisa mengandung pelecehan. Hal ini kadang terjadi karena nama anak terlalu sulit dilafalkan, baik oleh orang-orang disekitarnya bahkan bagi anaknya sendiri.

Nama yang unik dan berbeda apalagi megah, mungkin memiliki keuntungan tersendiri. Namun nama yang demikian dapat menyebabkan beberapa masalah. Nama yang sulit diucapkan dapat membuat orangorang sering salah mengucapkan atau menuliskannya. Ada suatu penelitian yang menunjukkan bahwa orang sering memberikan penilaian negatif pada seseorang yang memiliki nama yang aneh atau tidak biasa. Dr. Albert Mehrabian, PhD. melakukan penelitian tentang bagaimana sebuah nama mengubah persepsi orang lain tentang moral, keceriaan, kesuksesan, bahkan maskulinitas dan feminitas. Dalam pergaulan anak yang memiliki nama yang tidak biasa 
mungkin akan mengalami masamasa diledek atau diganggu oleh teman-temannya karena namanya dianggap aneh. Pernah mendengar ada seseorang yang bernama Rahayu ternyata seorang laki-laki?, atau mungkin penegalaman penulis juga, kebetulan penulis bernama Novita Trianto Hasibuan, berdasarkan pengalaman banyak orang mengira Trianto adalah laki-laki, kebetulan nama penulis diambil dari nama ayahnya yaitu Eddi Aryanto Hasibuan, dan semua saudara penulis juga mengikuti nama belakang ayah, yaitu Novita Trianto, Fitri Galunia Aryanto, Mega Erdiana Putri Aryanto. Contoh lain ada seorang anak di Padangmatinggi tepatnya di Padangsidimpuan bernama Erdiana, alasan orang tua memberikan nama tersebut yaitu karena itu gabungan dari nama ibu dan ayah Erdiana, "Er" yaitu Erni sedangkan "di" diambil dari nama belakang ayahnya yaitu Eddi.

Dari pengalaman penulis tersebut dapat disimpulkan bahwa orang tua mempunyai alasan tertentu untuk memberikan buah hati kepada anaknya. Sumber: (Dari Pengalaman Penulis)

\section{Hal yang Perlu Diperhatikan} dalam Memberi Nama yang Baik untuk Anak

Memberikan nama untuk anak memang gampang-gampang susah, kalau salah bisa menjadi beban untuk si anak, ada baiknya memberikan nama yang baik, karena nama merupakan harapan dan doa untuk anak tersebut. Adapaun yang perlu diperhatikan dalam memberi nama yang baik untuk anak antara lain:

1. Berikan nama yang mempunyai arti yang baik, pilah dan pilih nama tersebut dan cari tau artinya.

2. Jangan memberikan nama anak dengan nama yang serupa dengan orang kafir

3. Khususnya dalam islam tidak boleh memberikan nama dengan nama-nama Allah. Misalnya Alkhaliq ( pencipta)

4. Tahu asal idenya

Pernahkah Anda bertanya kepada orang tua mengenai asal usul nama Anda? Kebanyakan 
orang melakukan hal itu.

Kemungkinan terbesar pula, si anak akan bertanya hal yang sama. Ia pasti akan merasa sangat kecewa bila jawaban orang tuanya hanya "Nama itu datang begitu saja", apalagi bila Anda tidak bisa mengingat hal yang mencetus nama itu. Jadi, coba siapkan waktu untuk memikirkan atau menciptakan nama untuk si anak.

Sumber : http: kopi ireng.com

Selain itu ada juga hal-hal yang perlu diperhatikan dalam memberi nama anak khususnya di Indonesia. Nama merupakan hak anak yang dijamin oleh peraturan perundangundangan, sebagai berikut:

a. Undang-Undang No. 39 Tahun 1999 tentang Hak Asasi Manusia, Pasal 53 ayat (2) yang berbunyi:

"Setiap anak sejak kelahirannya.berhak atas suatu nama dan status kewarganegaraan."

b. Undang-Undang No. 23 Tahun 2002 tentang Perlindungan Anak
("UU Perlindungan Anak"),

Pasal 5, yang berbunyi:

"Setiap anak berhak atas suatu nama sebagai identitas diri dan status kewarganegaraan."

Ketentuan hukum yang mengatur mengenai pemberian nama di Indonesia dapat ditemukan pada Kitab Undang-Undang Hukum Perdata, Buku Kesatu Bab II Bagian ke-2 tentang Nama-nama, perubahan nama-nama, dan perubahan namanama depan,yaitu mulai Pasal 5a s.d. Pasal 12. Di dalam Pasal 5a KUHP disebutkan bahwa:

"Anak sah serta anak tidak sah tetapi diakui oleh bapaknya, berhak menggunakan nama keturunan bapaknya. Jika anak tidak sah tidak diakui oleh bapaknya, maka memakai nama keturunan ibunya."

Meskipun tidak ada peraturan perundang-undangan yang mengatur tentang pemberian nama anak, orang tua diharapkan tetap memperhatikan salah satu prinsip dasar Konvensi Hak-Hak Anak sebagaimana diatur Pasal 2 huruf b UU Perlindungan Anak, yaitu kepentingan terbaik bagi anak. 


\section{METODOLOGI PENELITIAN}

\section{Sumber Data}

Menurut Arikunto, 1993:102

Sumber data adalah subjek dari mana data dapat diperoleh. Apabila penelitian menggunakan kuesioner atau wawancara dalam pengumpulan datanya, maka sumber data disebut responden, yaitu orang yang merespon atau menjawab pertanyaan penelitian baik pertanyaan tertulis maupun lisan diperoleh.

Sumber data dalam penelitian ini, peneliti mengambil daftar namanama orang dari daerah Mandailing secara umum dari facebook. Kemudian dari data-data tersebut penulis menindaklanjuti dengan mewawancarai orangtua dari anak tersebut dan secara umumnya peneliti mewawancara seorang cerdik pandai yang ada di kampung tersebut, untuk memperoleh arti dan alasan orang tuanya memberikan nama tersebut.

\section{Metode Penelitan}

Metode penelitian merupakan suatu cara untuk mendapatkan pemecahan terhadap masalah penelitian. Tujuan umum penelitian adalah untuk memecahkan masalah, maka langkah yang harus ditempuh relevan dengan masalah yang dirumuskan.

Sesuai dengan masalah yang akan diteliti, penulis menggunakan jenis penelitian deskriptif dan kualitatif. Penelitian deskriptif adalah penelitian yang berusaha menggambarkan dan menginterpretasi objek sesuai dengan apa adanya.

Hal serupa dikemukakan oleh Sugiyono (2007: 21) yang mendefenisikan metode deskriptif sebagai, "metode yang berfungsi untuk mendeskripsikan atau memberi gambaran terhadap objek yang diteliti melalui data sampel atau populasi sebagaimana adanya, setelah itu melakukan analisis dan membuat kesimpulan yang berlaku untuk umum."

Sedangkan penelitian kualitatif penelitian yang berlandaskan pada filsafat postpositivisme, digunakan untuk meneliti pada kondisi obyek yang alamiah, (sebagai lawannya adalah 
eksperimen) dimana peneliti adalah sebagai instrumen kunci, pengambilan sampel sumber data dilakukan secara purposive dan snowbaal, teknik pengumpulan dengan trianggulasi (gabungan), analisa data bersifat induktif /kualitatif, dan hasil penelitian kualitatif lebih menekankan makna dari pada generalisasi (Sugiyono, 2007: 15).

Berdasarkan jenis penelitian yang dilaksanakan yaitu deskriptif dan kualitatif, maka metode penelitian yang digunakan adalah survey. Menurut Sugiyono (2007: 12) metode survey merupakan metode penelitian yang digunakan untuk mendapatkan data dari tempat tertentu yang alamiah (bukan buatan), tetapi peneliti melakukan perlakukan dalam pengumpulkan data, misalnya dengan wawancara tersetruktur, dan sebagainya (pelakuan tidak seperti dalam ekperimen).

Menurut Mahsun (2006:251) Metode wawancara atau interview merupakan salah satu metode yang digunakan dalam tahap penyediaan data yang dilakukan dengan cara peneliti melakukan percakapan atau kontak dengan penutur selaku narasumber. Teknik catat yaitu teknik pengumpulan data yang dilakukan dengan cara mencatat data- data yang berkaitan dengan objek penelitian. Teknik catat ini digunakan oleh peneliti untuk mencatat data- data yang berupa kata dalam nama diri.

\section{Teknik Pengumpulan dan}

\section{Pengolahan data}

Data yang digunakan dalam penelitian ini adalah data sekunder yaitu data yang diperoleh melalui dokumentasi yang ada di facebook berupa biodata seseorang. Menurut Sugiyono (2007: 129)," Sumber sekunder merupakan sumber yang tidak langsung memberikan data kepada pengumpul data, misalnya lewat orang lain atau lewat dokumen"

Untuk mengetahui hubungan nama anak dengan harapan orang tua, peneliti melakukan beberapa tahapan-tahapan sebagai berikut:

1. Mendapatkan data berupa nama-namaorang Mandailing dari media sosial facebook. 
2. Mewawancarai orang tua anak yang kebetulan PEMBAHASAN HASIL namanya ada dalam facebook tersebut serta mewawancarai salah seorang cerdik pandai di salah satu daerah Mandailing tepatnya di Padangsidimpuan untuk mengetahui apa arti nama orang mandailing tersebut dan apa kira-kira alasan orang tua memberikan nama tersebut secara umum.

3. Melakukan pengolahan data yang telah didapat, kemudian melakukan analisis untuk mendapatkan hubungan dari nama-nama tersebut dengan harapan orang tuanya.

4. Berdasarkan analisis tersebut akan diambil kesimpulan.

\section{PENELITIAN}

\section{Deskripsi Data}

Daftar nama-nama orang Mandailing diperoleh dari facebook baik nama laki-laki dan perempuan dari berbagai daerah di Mandailing.
Analisis Data
Berdasarkan
data-data penelitian yang diperoleh, penulis membuat pengelempokan nama- nama siswa ke dalam bentuk tabel. Pengelompokan tersebut dibagi berdasarkan nama, jenis kelamin, asal, arti nama, alasan pemberian nama. Untuk lebih jelas penulis akan memaparkan gambar tabel pengelompokan nama-nama sebagai berikut:

Nama-nama Orang Mandailing

\begin{tabular}{|c|l|c|l|l|l}
\hline No & Nama Anak & $\begin{array}{c}\text { Jenis } \\
\text { Kelamin }\end{array}$ & \multicolumn{1}{|c|}{ Asal } & Arti Nama & $\begin{array}{c}\text { Alasan } \\
\text { Pemberian } \\
\text { Nama }\end{array}$ \\
\hline $\mathbf{1}$ & $\begin{array}{c}\text { Rahmad } \\
\text { Kuaso } \\
\text { Dongoran }\end{array}$ & L & Padangsidimpuan & Berkuasa & $\begin{array}{c}\text { Agar anaknya } \\
\text { kelak menjadi } \\
\text { orang besar }\end{array}$ \\
\hline 2 & $\begin{array}{l}\text { Pardamean } \\
\text { Siregar }\end{array}$ & L & Padangsidimpuan & Damai & $\begin{array}{l}\text { Agar hatinya } \\
\text { damai }\end{array}$ \\
\cline { 1 - 4 } 3 & $\begin{array}{l}\text { Sangkot M } \\
\text { Hasibuan }\end{array}$ & L & Padangsidimpuan & Gantung & $\begin{array}{l}\text { Sewaktu lahir } \\
\text { anaknya susah }\end{array}$ \\
\hline
\end{tabular}




\begin{tabular}{|c|c|c|c|c|c|}
\hline & & & & & dilahirkan \\
\hline 4 & Putri Saima & $\mathrm{P}$ & Padangsidimpuan & Cukup & $\begin{array}{l}\text { Orang tuanya } \\
\text { berharap } \\
\text { cukuplah anak } \\
\text { perempuan, } \\
\text { semoga } \\
\text { dikaruniai anak } \\
\text { laki-laki }\end{array}$ \\
\hline 5 & $\begin{array}{l}\text { Foda Farona } \\
\text { Deges }\end{array}$ & $\mathrm{P}$ & Padangsidimpuan & Cantik & $\begin{array}{l}\text { Agar perangai } \\
\text { anaknya bagus }\end{array}$ \\
\hline 6 & Ahmad Saipe & $\mathrm{L}$ & Padangsidimpuan & Cukup & $\begin{array}{l}\text { Cukuplah } \\
\text { anaknya yang } \\
\text { laki-laki, orang } \\
\text { tuanya berharap } \\
\text { anak perempuan }\end{array}$ \\
\hline 7 & $\begin{array}{l}\text { Moga } \\
\text { Marina }\end{array}$ & $\mathrm{L}$ & Padangsidimpuan & $\begin{array}{l}\text { Moga : } \\
\text { semoga } \\
\text { Marina: } \\
\text { beribu }\end{array}$ & $\begin{array}{l}\text { Semoga anak } \\
\text { tersebut } \\
\text { berbakti kepada } \\
\text { ibu }\end{array}$ \\
\hline 8 & Minta Ito & $\mathrm{L}$ & Padangsidimpuan & Laki-laki & $\begin{array}{l}\text { Orang tuanya } \\
\text { berharap } \\
\text { mempunyai } \\
\text { anak laki-laki } \\
\text { lagi }\end{array}$ \\
\hline 9 & $\begin{array}{l}\text { Pardomuan } \\
\text { Lubis }\end{array}$ & $\mathrm{L}$ & Pdangsidimpuan & Pertemuan & $\begin{array}{l}\text { Agar anaknya } \\
\text { kelak bertemu } \\
\text { dengan orang } \\
\text { baik }\end{array}$ \\
\hline 10 & $\begin{array}{l}\text { Togar } \\
\text { Simatupang }\end{array}$ & $\mathrm{L}$ & Padangsidimpuan & Tegar & $\begin{array}{l}\text { Agar anaknya } \\
\text { tegar } \\
\text { menghadapi } \\
\text { masalah }\end{array}$ \\
\hline 11 & Togap & $\mathrm{L}$ & Padangsidimpuan & $\begin{array}{l}\text { Kuat, kekar, } \\
\text { kokoh }\end{array}$ & $\begin{array}{l}\text { Agar anaknya } \\
\text { menjadi orang } \\
\text { yang kuat }\end{array}$ \\
\hline 12 & Saut & $\mathrm{L}$ & Pdangsidimpuan & Jadi & $\begin{array}{l}\text { Agar anaknya } \\
\text { menjadi }\end{array}$ \\
\hline 13 & Parulian & $\mathrm{L}$ & Gunungtua & $\begin{array}{l}\text { Cantik, } \\
\text { ganteng, }\end{array}$ & $\begin{array}{l}\text { Agar anaknya } \\
\text { menjadi orang } \\
\text { yang cantik hati } \\
\text { dan wajahnya }\end{array}$ \\
\hline
\end{tabular}




\begin{tabular}{|c|c|c|c|c|c|}
\hline & & & & elok & \\
\hline 14 & $\begin{array}{l}\text { Laungan } \\
\text { Martua }\end{array}$ & $\mathrm{L}$ & Padangsidimpuan & Dihormati & $\begin{array}{l}\text { Agar anaknya } \\
\text { menjadi orang } \\
\text { terhormat }\end{array}$ \\
\hline \multirow[t]{2}{*}{15} & \multirow[t]{2}{*}{$\begin{array}{l}\text { Monang } \\
\text { Daulay }\end{array}$} & \multirow[t]{2}{*}{$\mathrm{L}$} & & \multirow[t]{2}{*}{ Menang } & \multirow[t]{2}{*}{$\begin{array}{l}\text { Agar } \\
\text { kemenangan } \\
\text { menyertai } \\
\text { anaknya }\end{array}$} \\
\hline & & & Padangsidimpuan & & \\
\hline 16 & $\begin{array}{l}\text { Mustafa } \\
\text { Parlindungan }\end{array}$ & $\mathrm{L}$ & Pdangsidimpuan & Perlindungan & $\begin{array}{l}\text { - nama } \\
\text { kakeknya }\end{array}$ \\
\hline 17 & $\begin{array}{l}\text { Andri } \\
\text { Halomoan }\end{array}$ & $\mathrm{L}$ & Pdangsidimpuan & Yang disukai & $\begin{array}{l}\text { Berharap } \\
\text { anaknya disukai } \\
\text { orang }\end{array}$ \\
\hline 18 & Gabe Marihot & $\mathrm{L}$ & Padangsidimpuan & Kaya & $\begin{array}{l}\text { Berharap } \\
\text { anaknya } \\
\text { menjadi orang } \\
\text { besar dan kaya }\end{array}$ \\
\hline 19 & Tigor Siregar & $\mathrm{L}$ & Padangsidimpuan & Lurus, patuh & $\begin{array}{l}\text { Agar anaknya } \\
\text { menjadi anak } \\
\text { yang patuh }\end{array}$ \\
\hline 20 & $\begin{array}{l}\text { Timbul } \\
\text { Siregar }\end{array}$ & $\mathrm{L}$ & Simangambat & Kelihatan & $\begin{array}{l}\text { Pas ibunya } \\
\text { melahirkan } \\
\text { anaknya susah } \\
\text { lahir dan } \\
\text { akhirnya } \\
\text { kelihatan }\end{array}$ \\
\hline 21 & Hotnida Sari & $\mathrm{P}$ & Kota Pinang & Kuatlah, erat & $\begin{array}{l}\text { semoga } \\
\text { pancaran mata } \\
\text { perempuan } \\
\text { yang dapat } \\
\text { menjadi mandiri }\end{array}$ \\
\hline 22 & $\begin{array}{l}\text { Maraganti } \\
\text { Hasonangan }\end{array}$ & $\mathrm{L}$ & Padangsidimpuan & Kebahagiaan & $\begin{array}{l}\text { semoga menjadi } \\
\text { anak yang }\end{array}$ \\
\hline
\end{tabular}




\begin{tabular}{|c|c|c|c|c|c|}
\hline & & & & & bahagia selalu \\
\hline 23 & Gongmatua & $\mathrm{L}$ & Padangsidimpuan & Kuatlah & $\begin{array}{l}\text { harapan orang } \\
\text { tua menjadi } \\
\text { anak kuat }\end{array}$ \\
\hline 24 & Hotmatua & $\mathrm{L}$ & Padangsidimpuan & Erat, kuat & $\begin{array}{l}\text { Menjadi anak } \\
\text { yang kuat }\end{array}$ \\
\hline 25 & $\begin{array}{l}\text { Raja Bonar } \\
\text { Siregar }\end{array}$ & $\mathrm{L}$ & Sipirok & Benar, jujur & $\begin{array}{l}\text { Agar menjadi } \\
\text { orang yang } \\
\text { selalu jujur dan } \\
\text { adil }\end{array}$ \\
\hline 26 & Efi Anjuli & $\mathrm{P}$ & Padangsidimpuan & $\begin{array}{l}\text { Berlaku } \\
\text { sabar }\end{array}$ & $\begin{array}{l}\text { menjadi anak } \\
\text { soleh dan } \\
\text { penyabar }\end{array}$ \\
\hline 27 & $\begin{array}{l}\text { Hotma } \\
\text { Nasution }\end{array}$ & $\mathrm{P}$ & Padangsidimpuan & Kuatlah, erat & $\begin{array}{l}\text { semoga menjadi } \\
\text { anak yang kuat }\end{array}$ \\
\hline 28 & $\begin{array}{l}\text { Apriliya } \\
\text { Duma }\end{array}$ & $\mathrm{P}$ & Padangsidimpuan & $\begin{array}{l}\text { Makmur, } \\
\text { sejahtera }\end{array}$ & $\begin{array}{l}\text { jadi anak yang } \\
\text { baik }\end{array}$ \\
\hline 29 & $\begin{array}{l}\text { Moratua } \\
\text { Naibaho }\end{array}$ & $\mathrm{L}$ & Sipirok & Dihormati & $\begin{array}{l}\text { semoga cita- } \\
\text { citanya tercapai } \\
\text { setinggi } \\
\text { tingginya, dan } \\
\text { anaknya dan } \\
\text { dihormati }\end{array}$ \\
\hline
\end{tabular}




\begin{tabular}{|c|c|c|c|c|c|}
\hline 30 & $\begin{array}{l}\text { Tondi } \\
\text { Hasibuan }\end{array}$ & $\mathrm{L}$ & Padangsidimpuan & $\begin{array}{l}\text { Roh, raga, } \\
\text { jiwa }\end{array}$ & $\begin{array}{l}\text { bagaimanapun } \\
\text { suasananya dia } \\
\text { akan } \\
\text { memberikan } \\
\text { keindahan } \\
\text { dimata keluarga } \\
\text { dan sekitarnya. }\end{array}$ \\
\hline 31 & $\begin{array}{l}\text { Togu } \\
\text { Khairani }\end{array}$ & $\mathrm{P}$ & Padangsidimpuan & Berpegangan & $\begin{array}{l}\text { menjadi anak } \\
\text { yang selalu } \\
\text { dipuja dan } \\
\text { membawa } \\
\text { harum dan } \\
\text { selalu } \\
\text { berpegang pada } \\
\text { kebaikan }\end{array}$ \\
\hline 32 & $\begin{array}{l}\text { Lambok } \\
\text { Sagala }\end{array}$ & $\mathrm{L}$ & Padangsidimpuan & Lembut & $\begin{array}{l}\text { jadi anak yang } \\
\text { taat /amanah } \\
\text { bagi bangsa dan } \\
\text { negara, dan } \\
\text { lembut dan } \\
\text { tidak kasar }\end{array}$ \\
\hline 33 & Baha Siregar & $\mathrm{L}$ & Padangsidimpuan & Sifat, watak & $\begin{array}{l}\text { semoga menjadi } \\
\text { cahaya } \\
\text { kebaikan dan } \\
\text { berwatak baik }\end{array}$ \\
\hline 34 & $\begin{array}{l}\text { Parmohonan } \\
\text { NST }\end{array}$ & $\mathrm{L}$ & Panyabungan & Permohonan & $\begin{array}{l}\text { Semoga apa-apa } \\
\text { yang } \\
\text { dimohonkan } \\
\text { sang anak } \\
\text { kepada sang } \\
\text { pencipta } \\
\text { dikabulkan. }\end{array}$ \\
\hline
\end{tabular}


Dari tabel di atas kita dapat melihat bahwa nama-nama orang mandailing terjadi hubungan erat antara nama anak dengan harapan orang tuanya sebagai seorang batak. Dilihat dari arti nama masing-masing siswa menunjukan makna nama yang mengagungkan, kemulyaan, kebaikan, kegagahan, kelembutan, pesona yang menawan, penghambaan, dan ketaatan. Para orang tua berusaha memberikan nama-nama anaknya dengan nama yang terbaik menurut mereka. Ada banyak hal yang mendasari orang tua memberikan nama anaknya seperti penamaan yang diambil dari nama tokoh, nama club sepakbola, nama sifat, nama bulan, nama silsilah keluarga, nama panca indra, namanama goib, nama gabungan kata, nama tingkatan anggota keluarga, makna kedudukan, nama tumbuhan dan nama peristiwa.

Untuk lebih jelas kita bisa melihat tabel persentase perbandingan orang Mandailing di antara daerah Padangsidimpuan, Panyabungan, Gunungtua, Simangambat. Kota Pinang, Sipirok. Berikut uraian nama menurut daerahnya.

TABEL NAMA ORANG MANDAILING DARI BEBERAPA DAERAH

\begin{tabular}{|c|l|c|c|}
\hline No. & \multicolumn{1}{|c|}{ Bahasa } & Jumlah & Persentase \% \\
\hline 1 & Padangsidimpuan & 28 & $82 \%$ \\
\hline 2 & Panyabungan & 1 & $3 \%$ \\
\hline 3 & Gunungtua & 1 & $3 \%$ \\
\hline 4 & Simangambat & 1 & $3 \%$ \\
\hline 5 & Kota Pinang & 1 & $3 \%$ \\
\hline 6 & Sipirok & 2 & $6 \%$ \\
\hline & Jumlah & 34 orang & $100 \%$ \\
\hline
\end{tabular}


Dari tabel di atas kita dapat mengambil gambaran, bahwa pengaruh sosial, budaya, agama, politik, dan ekonomi bisa memengaruhi kepribadian individu, terutama memengaruhi pola pikir individu tersebut. Pola pikir yang terbentuk dalam pribadi seseorang akan memengaruhi cara pandangnya dalam menjalani kehidupan bermasyarakat. Khususnya dalam

\section{PENUTUP}

\section{Simpulan}

Bedasarkan kajian di atas, dapat disimpulkan bahwa kedudukan nama pada seseorang berfungsi sebagai bahasa komunikasi dan identitas diri dari pemilik namanya. Kedudukan nama bukan hanya mewakili identitas diri dari pemiliknya, tetapi bisa juga mewakili jalan pikiran dari orang tuanya.

Nama yang diberikan orang tua kepada anaknya akan memengaruhi kepribadian, kemampuan anak dalam berinteraksi dengan orang lain, dan bagaimana cara orang menilai diri pemilik namanya. persoalan ini, orang tua yang memberi nama anaknya tergantung pola pikir yang ia bentuk dalam dirinya.

Salah satu dampak yang terlihat pada saat ini dari pengaruh budaya barat adalah harapan orang tua terhadap nama anaknya yang mengidolakan artis-artis, tokohtokoh dan nama-nama dari istilah barat supaya terlihat modern.

\section{Saran}

Diharapkan pembaca bisa memilih nama yang sesuai dengan keinginannya tetapi juga mempunyai makna yang baik. Pemberian nama kepada seseorang diharapkan tidak hanya asal memberikan nama, tetapi juga mengandung makna dan diharapkan nantinya anak tersebut akan menjadi orang sesuai dengan pemberian namanya, sebab nama adalah salah satu cara untuk memberikan sebuah doa.

\section{Daftar Pustaka}

Arikunto, Suharsini. 1993. Prosedur Penelitian Suatu Pendekatan Praktik. Jakarta: Rineka Cipta.

Cavallaro, D. (2001). Critical and Cultural Theory: Thematic 
Variation. The Althone Press London \& New Brunswick, NJ

Departemen Pendidikan Nasional. 2008. Kamus Besar Bahasa

Indonesia. Jakarta:

Gramedia Pustaka Utama.

Djajasudarma, Fatimah. 1999. Semantik 1: Pengantar ke Arah Ilmu Makna. Bandung: Refika Aditama.

Hofmann, T. R. (1993). Realms of Meaning. New York: Longman Publishing

Mahsun. 2006. Metode Penelitian

Bahasa: Tahapan Strategi, Metode, dan Tekniknya . Jakarata: Raja Grafindo

Suaramerdeka.(2011).Do'a Serta

Harapan Di Balik Nama Bayi.

Tersedia Dalam:

Suaramerdeka.com.

November 2011.

Suharno. (1987) Sistem Nama Diri dalam Masyarakat Jawa (Laporan Penelitian). Yogyakarta: Proyek Pembinaan Bahasa dan Sastra Indonesia dan Daerah DIY. Depdikbud.

Sugiyono. 2007. Metode Penelitian Pendidikan Pendekatan
Kuantitatif, Kualitatif, dan

$R \& D$. Bandung: Alfabeta.

Suranto, A. (1983). Studi tentang Sistem Nama-nama Jawa Surakarta: Fakultas Sastra UNS

http: kopi ireng.com

Wibowo, Mashudi Ridha. 2001. “ Nama Diri Etnik Jawa”. Jurnal Humaniora. Vol. XIII, No.1 Februari 2001. Halaman 44-45. ( http:

//jurnal.ugm.ac.id/index.php/jurn al-humaniora).

Zunairoh, ratna. 2014. Jurnal Analisis Semantik Nama Orang Jawa di Desa Karangduwur Kecamatan Petahanan Kabupaten Kebumen. Jawa: Universitas Muhammadiyah Purworejo. 
